\title{
Covid-19: The Effect of Person-Environment Misfit and Job Insecurity on Employee Turnover Intention
}

\section{Mutiiah Mohamad, Abdul Kadir Othman, Ahmad Suffian Mohd Zahari}

To Link this Article: http://dx.doi.org/10.6007/IJARBSS/v12-i1/11508 DOI:10.6007/IJARBSS/v12-i1/11508

Received: 07 November 2021, Revised: 08 December 2021, Accepted: 27 December 2021

Published Online: 10 January 2022

In-Text Citation: (Mohamad et al., 2022)

To Cite this Article: Mohamad, M., Othman, A. K., \& Zahari, A. S. M. (2022). Covid-19: The Effect of PersonEnvironment Misfit and Job Insecurity on Employee Turnover Intention. International Journal of Academic Research in Business and Social Sciences, 12(1), 437-448.

Copyright: (c) 2022 The Author(s)

Published by Human Resource Management Academic Research Society (www.hrmars.com) This article is published under the Creative Commons Attribution (CC BY 4.0) license. Anyone may reproduce, distribute, translate and create derivative works of this article (for both commercial and non0-commercial purposes), subject to full attribution to the original publication and authors. The full terms of this license may be seen at: http://creativecommons.org/licences/by/4.0/legalcode

Vol. 12, No. 1, 2022, Pg. $437-448$

Full Terms \& Conditions of access and use can be found at http://hrmars.com/index.php/pages/detail/publication-ethics 


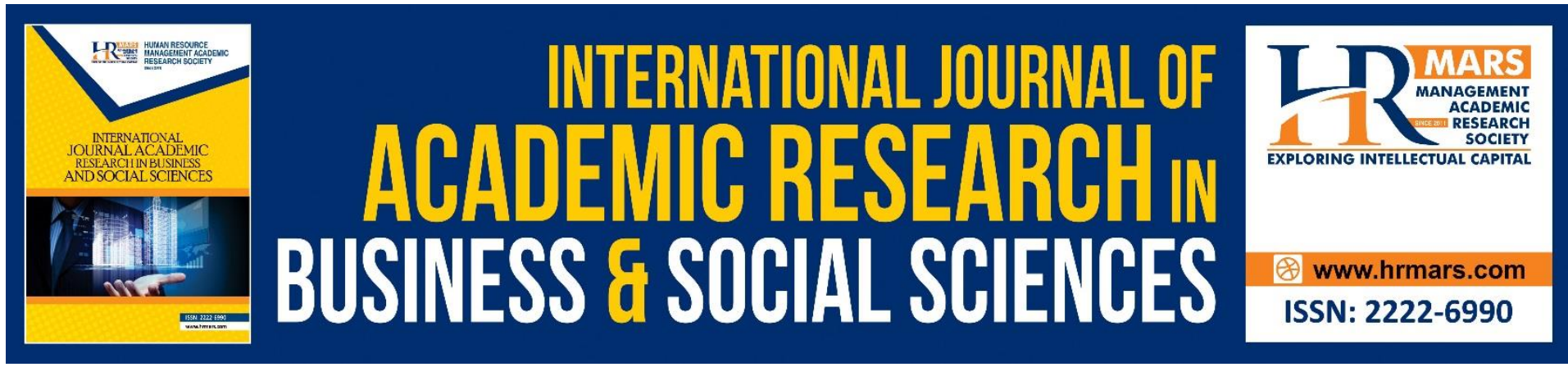

\title{
Covid-19: The Effect of Person-Environment Misfit and Job Insecurity on Employee Turnover Intention
}

\author{
Mutiiah Mohamad ${ }^{1}$, Abdul Kadir Othman², Ahmad Suffian Mohd \\ Zahari ${ }^{3}$ \\ 1,2Faculty of Business and Management, Universiti Teknologi MARA, Shah Alam, Selangor, \\ Malaysia, ${ }^{3}$ Faculty of Business and Management, Universiti Teknologi MARA, Cawangan \\ Terengganu, Malaysia \\ Email: mutiiahmohamad@gmail.com
}

\begin{abstract}
The 2019 coronavirus disease (COVID-19) is a public health emergency of international concern and poses a challenge to public psychological resilience. With regards to the COVID19 pandemic, organizations suddenly need to navigate the unprecedented, related effects on employee turnover issues. Furthermore, this dramatic change caused unprecedented profound implications not only on employees but also companies around the globe as a whole. Thus, the study drew on the factors that are related to turnover which are job insecurity and person-environment misfit. In this study, Conservation of Resources (COR) theory was chosen to provide a theoretical perspective in explaining the related factors with turnover intention. On the other hand, several drawbacks of turnover intention are also highlighted throughout the literature review. Some measures to address the turnover issues by the organizations are discussed.
\end{abstract}

Keywords: COVID-19, Job Insecurity, Person-Environment Misfit, Turnover Intention

\section{Introduction}

Globally, as of 10:46am, $26^{\text {th }}$ July 2021, the Coronavirus (COVID-19) pandemic has caused $193,798,265$ confirmed cases, including 4,158,041 deaths worldwide (WHO, 2021). To cope with the uncontrollable spread of the virus, measures such as social distancing, self-isolation and travel restrictions have been enforced by many countries, industries and companies worldwide, which has led to a reduction in workforce in all economic sectors and the loss of jobs, resulting in cessation of many economic activities. The Malaysian government began implementing the Movement Control Order (MCO) on March 18 $8^{\text {th }}, 2020$ to break the chain of the COVID-19 pandemic.

With the recent updates on the COVID-19 outbreak, organizations are facing huge challenges on a global scale, forcing them to dive in and getting directly involved in an unprecedented circumstance in order to survive. Due to the COVID-19 pandemic, the workforce 
characteristics have dramatically changed with regard to their psychosocial, technical and physical aspects. In addition, when employees are instructed to work from home, they often feel high levels of stress, fear and insecurity of losing their jobs (Jung et al., 2021). Most of them experienced difficulties in adapting to the new work norms and meeting the expectations. As a result, the organization experiences a high turnover rate (Dhanpat et al., 2019).

In the reality of the modern working environment, feelings of uncertainty among employees is increasing due to various reasons including economic fluctuations, technological changes and political insecurity, and it is impossible to guarantee employees' work stability as per before COVID-19 (Etehadi \& Karatepe, 2019). This matter becomes a serious concern among employees. Organizational restructuring and downsizing increase employees' perception of insecurity in their job and position, leading to uncertainty and fear of losing their job (Brougham \& Haar, 2020). Typically, there are two specific reasons for the heightened concern of job insecurity among employees (Nugraha \& Garin, 2019). First, organizational changes caused by downsizing and mergers. Second, certain threats emerge due to overlapping work or positions in the organizations.

This phenomenon of job insecurity often resulted from the study of the employee in the organization. Among these employees, those who play an essential role in dealing with the customers, being the key contacts in the organization are prone to experience job insecurity and have the intention to leave the organization (Elmadağ \& Ellinger, 2018). This turnover often occurs when they have reduced motivation, increased anxiety with their role and felt insecure with their job (Akgunduz \& Eryilmaz, 2018).

Furthermore, COVID-19 has created an extremely big challenge in handling employees. Employees must quickly adapt to remote work environment due to new norms and drastically change their former routine of which they spent most of their time working at their organization. This situation has posed a great challenge to Human Resource Management to wisely manage this new work environment. This may limit the segmentation between private and work spheres and create difficulties in breaking away from job demands (Chawla et al., 2020). In addition, the risk of feeling lonely, lack of purpose, and being associated with negative effects on well-being are some of the negative consequences due to this new altered working conditions (Achor et al., 2018). Despite the effects of the economic recession, the current challenge of COVID-19 provides management and scholars with an opportunity to coordinate research and turn it into actionable insights to help organizations deal with one of the greatest challenges in modern history especially on handling the employee person-environment misfit and employee job insecurity.

\section{Objective}

This study aimed to synthesized and integrate conceptual research on the relationship of person-environment misfit and job insecurity on turnover intention in the Covid-19 pandemic. 


\section{Literature Review \\ Person-Environment Misfit}

Person-environment misfit refers to a perceived mismatch between the individual and the environment, on a dimension that is salient to one or both parties, and relates to individual factors that are more than, or less than, or qualitatively different from the comparable factors at the organization level (Cooper-Thomas \& Wright, 2013). The concept of personenvironment misfit provides a framework and insights into understanding employee attitudes and behaviours. As research on the concept progresses, researchers begin to distinguish between the types of fit that exist under the generic concept of personenvironment fit (Kniffin et al., 2021; Tong et al., 2015). Perceived mismatch between the individual and the environment can broadly be defined as person-environment misfit. It relates to the dimensions that are projecting one or both parties with regard to particularly personal factors rather than comparable factors at the organizational level.

One of the most widely used frameworks in person-environment fit research, the attractionselection-attrition framework (Memon et al., 2018) that proposes that when individuals' values match or are similar, they will feel attracted to and be selected by the organization. Moreover, when there is no deviation in the similarity of values over time, these people will be retained by these organizations. This imparts an acceptable level of person-environment fit, and associated with positive work outcomes.

The relationship between person-environment fit and actual employee turnover or the intention to leave the organization cannot be simply illustrated using a simple linear relationship. Other factors might affect the relationship between the two constructs. In this sense, employees who are incompatible with the organization only intend to leave when there are other job prospects and offers (Tong et al., 2015; Williamson \& Perumal, 2021). Additionally, job satisfaction has been shown to mediate the relationship between turnover intention and person-environment misfit. It was shown that employees who are satisfied with their organization and not having the erosion of fit tend to stay with the company and not keen for better job opportunities and opted to stay loyal to the organization.

\section{Job Insecurity}

Previously, the terms of employees' fear of losing their jobs and unemployment have been used to describe job insecurity (Jung et al., 2021). Inability to maintain ideal continuity in a threatened employment situation can be defined as job insecurity (Greenhalgh \& Rosenblatt, 2010). Impaired psychological health of employees and reduced motivation can be the consequences that may affect employees who experience job insecurity (Dhanpat et al., 2019; Griep et al., 2021; Urbanaviciute et al., 2019). Additionally, job insecurity also can be the results of organizational changes such as technological changes, mergers and acquisitions, and increased competition (Brougham \& Haar, 2020). Considering that, the rapidly changing business environment in the past three decades has led to an increase in job insecurity in various professions and industries.

On the other hand, in spite of these recent findings about the analysis on job insecurity and turnover intention, the meta-analysis based on 25,000 employees estimated true correlation (0.52) on job insecurity towards turnover intentions (Chan Yin-Fah et al., 2010; Cheng \& Chan, 2008). A more recent meta-analysis reported by Miana et al. (2011) provides strong 
support linking job insecurity to employee outcomes, such as job satisfaction and turnover intention. Consequently, employees who think their jobs are threatened and experience job insecurity are more likely to report dissatisfaction in their job, and seek job opportunities elsewhere.

The employees' most essential resources (e.g. energy and time) will be depleted when they feel threatened or when they experience job insecurity. Employees may try to withdraw from the stressful environment or think of turnover intention. Seeking new job opportunity and changing into the new job can be the option of withdrawing from the situation of job uncertainty and job insecurity (Filipkowski \& Johnson, 2008; Maertz \& Campion, 2004; Skelton et al., 2020). Cheng and Chan (2008) reported that employees who are experiencing job insecurity can affect their performance at work as these employees invest energy and spend much time in dealing with the threat of potentially losing their job. Over time, job insecurity may therefore result in losing the job involuntarily as employees can no longer fulfil the organization's expectations.

\section{Conservation of Resources Theory}

Conservation of Resources (COR) theory (Hobfoll, 1989) emphasizes objective elements of threat and loss, and common appraisals held jointly by people who share an environment, biology and culture (Hobfoll et al., 2018). As a job stress factor, job insecurity was found to be negatively correlated with employees' job satisfaction, job performance, psychological well-being, turnover intention and turnover (Williamson \& Perumal, 2021). According to the COR theory, when individuals perceive the threat of resource loss, and fail to obtain sufficient resources, emotional exhaustion will occur. Similarly, previous research reports stated that job insecurity may lead to loss of resources, burnout, emotional exhaustion, and decreased level of employee well-being (Chen \& Eyoun, 2021). In addition, employees' fear of COVID19 has led to work insecurity, because potential contagion risks and uncertain future economic situation may lead to layoffs. This encourages employees to invest extra energy in the workplace to keep their current positions and it leads to job stress and ultimately the intention to quit.

The same observation applies to the area of person-environment misfit. Wheeler et al. (2013) suggested using conservation of resources theory as an appropriate theoretical perspective to help us understand the consequences of this misfit. When there is loss of resources, employee will respond by being stressed out. In this case, resources are related to several factors that people consider important to achieve goals, such as values, working conditions, finances and personal characteristics. In summary, Hobfoll's (1989) COR model offers a theoretical guide for the literature in comprehending the connection between job insecurity and turnover intention and between person-environment misfit and turnover intention.

\section{Relationship between Person-Environment Misfit and Turnover Intention}

The COVID-19 pandemic poses a huge challenge to Human Resource Management that involves in drastically changing work conditions on new and current employees in the organization, such as shifting to "physical distancing and social distancing" work environment or revising and executing the company procedures and policies to limit human contact. In line with this situation, the employees are likely to experience important 
implications in the form of person-environment misfit, or the level of congruence between the attributes they possess and those of the environment due to the such dramatic alterations in the new norm in the organization (Carnevale \& Hatak, 2020; Kristof, 1996).

Due to the COVID-19 pandemic, experiencing misfit may be due to the growing gap between personal needs and the current work environment (Diab-Bahman \& Al-Enzi, 2020; Follmer et al., 2018). Employee adaptation to new environmental conditions in the organization cannot be simply realized without much effort. The possibility of having misfit as a result of changing work environment and conditions is high. The employees will feel dissatisfied as they missed the social interactions they had in their pre-pandemic work-lives (Fetters, 2020; Sacco \& Ismail, 2014). Building upon the work of Chawla et al (2020) regarding the daily recovery activities of employees in the new norm, for instance, employees are emotionally affected during the recovery process when engaging in virtual social activities with colleagues as a replacement for face-to-face social gatherings. Hence, the organization must have a better understanding on how these transformed community-building practices can be implemented without creating person-environment misfit.

Due to the high unemployment rate during the COVID-19 pandemic, leaving the organization may not be the right decision in a high competition labour market. Employees who experienced person-environment misfit tend to leave the organization. However, scholars have questioned whether these individuals (with misfit), would instantaneously exit their organizations or just get on with the turnover intention in adapting to the new norms of environmental condition (Memon et al., 2018; Tong et al., 2015; Uppal, 2020). In order to express feelings of stress, dissatisfaction and frustration, individuals who experience misfit are acting to express rebellion, disaffection, and malcontent and are not always persuaded into exiting their organizations (Williamson \& Perumal, 2021).

The connection between person-environment fit and employee actual turnover or turnover intention is complicated and cannot be explained using a simple linear relationship. A lot of factors need to be considered before the decision can be achieved. However, holding other factors constant, Cooper-Thomas and Wright (2013) reported that employees who experience misfit with their organizations, apparently tend to find and are keen to find better opportunity that fits well with their well-being and will leave the company and grab the opportunity when better job prospects exist. Therefore, the following proposition is made:

Proposition 1: There is a positive relationship between person environment misfit and turnover intention.

\section{Relationship between Job Insecurity and Turnover Intention}

The COVID-19 pandemic which rapidly sweeps across the world induces a considerable degree of unprecedented fear. In a study conducted by Kniffin et al (2021), employees who remained employed in organizations during economic downturns may experience job insecurity due to poor physical and mental health, prolonged furloughs, reduced salaries and working hours, and challenging circumstances. In addition to the immediate impact of COVID-19, there is also likely to be a diverse range of social-psychological effect, which are the employees are uncertain with their job and fear of losing their job. 
Furthermore, job insecurity can be due to lack of control and experience by the employees during times of uncertainty and fear or losing their job position in the organization. Additionally, it was also found that the high national unemployment rate was also associated with employees' job insecurity and became one of the factors of job insecurity (Chen \& Eyoun, 2021). Moreover, a recent study on employment found that $21.1 \%$ of the employees in organizations expressed their fear of losing their job and felt job insecurity meanwhile $51.9 \%$ of the employees believed that there is an opportunity of future job offer although they were unpleasantly affected due to the COVID-19 (International Labour Organization, 2020).

A considerable amount of literature has been published on job insecurity and turnover intention. Van Hootegem et al. (2019) reported that perceived job insecurity increases an employee's turnover intention. Similarly, Arijanto et al. (2020) argued that job insecurity is a potential cause of increasing employee turnover intention. However, Nella et al. (2015) distinguished that the effects of job insecurity widely contribute positively rather than negatively towards turnover intention among the employees. It is worsened when the case is connected with stress which increases employee turnover intention.

A study by Adewale (2015) noted that managing the stress caused by job insecurity is critical to reduce turnover intention, because acknowledged job insecurity will increase the tendency of employees to leave the organization. In addition, Stiglbauer et al. (2012) believed that there is a particularly strong relationship between job insecurity and turnover intention, therefore reducing job insecurity will decrease turnover intention. Hence, job insecurity has a clear association with turnover intent and this is also supported by Lee and Jeong (2017) and Akgunduz and Eryilmaz (2018). Taking these situations into account, it is believed that efforts should be made to reduce perceived job insecurity in order to avoid the loss of talented employees (Urbanaviciute et al., 2020). Karatepe et al. (2020) found that when organizations hinder employees from fulfilling their basic needs, the employee job insecurity will be affected and this can influence their turnover intention. Accordingly, the following proposition is made:

P2: There is a positive relationship between job insecurity and turnover intention.

\section{Conceptual Framework}

Due to the COVID-19 pandemic, employees in organizations are facing person-environment misfit and job insecurity. This paper aims to provide a conceptual framework that highlights the antecedents of turnover intention based on the insights from the literature. The purpose of this study is to examine whether person-environment misfit and job insecurity are related to turnover intention and more specifically whether these antecedents have the effects on turnover during this pandemic. In the long run, individuals with a higher-level of misfit and job insecurity would tend to leave the organization. Figure 1 shows the conceptual framework of the study. 


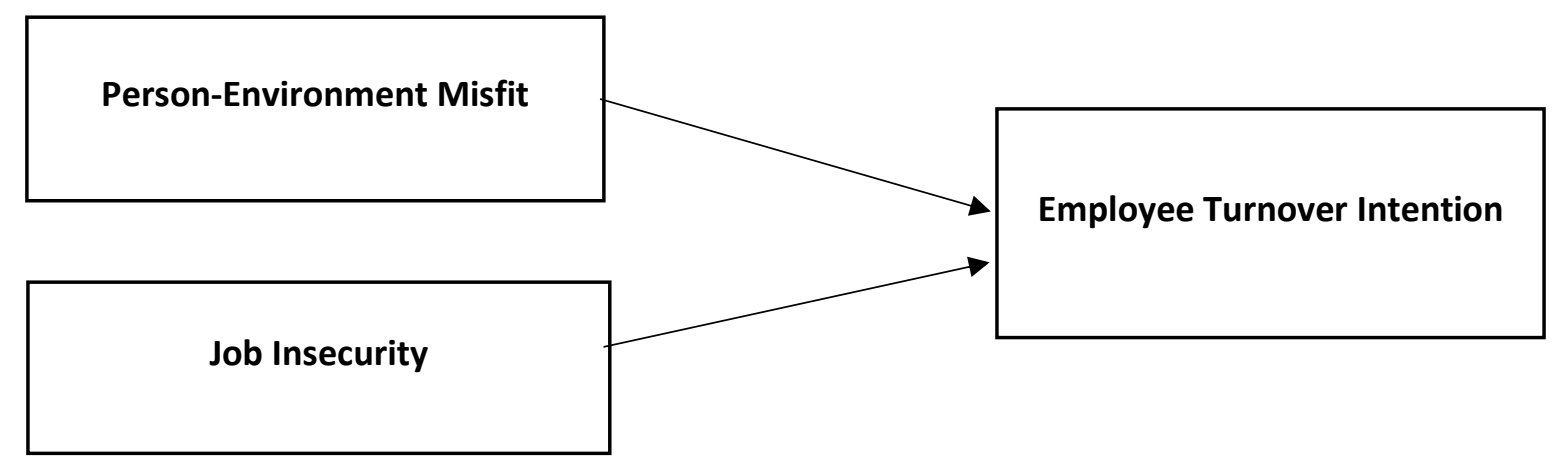

Figure 1: Conceptual Framework

\section{Conclusion and Recommendation}

Although the long-term impact of COVID-19 is currently unclear, there is no reason to believe that its impact on the life of the organization will be short-lived. As health experts have warned, the impact of the current pandemic is far from over (Hixon, 2020), but the risk of this far-reaching health crisis in the future is almost certain (Desmond-Hellmann, 2020). Therefore, our approach must be creating a vision of the future, assuming that the great challenge we are currently facing is not a unique and abnormal event, but constitutes a "new reality", which offers new opportunities that both academics and students and organizational professionals need. We need to stay focused. To this end, the current discussion has taken a step in this direction by highlighting some of the impact of COVID-19 on the person-environment fit and employees' well-being.

It is actually important to enhance employee well-being at work to produce positive work outcomes. Researchers and academicians have long insisted that a supportive work environment can promote teamwork and encourage employees to explore their skills, because such an environment provides the necessary conditions for productive work performance and employee loyalty (Al-Omari \& Okasheh, 2017; Awan \& Tahir, 2015). Therefore, human resource management needs to find ways to promote employee wellbeing especially by considering the implementation of job recognition scheme when achieving job goals, which is now becoming a labour standard because performance goals are tied to rewards, like promotions, performance rewards, and others. As a result, work pressure is reduced (Kim \& Kim, 2020), which can positively affect employees' job security and prevent them from quitting. In this context, setting appropriate work goals and consultation between management and employees will help reduce unnecessary stress, improve employees' sense of security at work, and reduce their intention to leave.

Having person-environment fit is consistent with the current idea of aligning employees with the organization (Huang et al., 2019). In order to enable employee engagement, personenvironment fit should serve as the stimulus to the employee to perform at their upmost potential to achieve high performance (Chi et al., 2020). In addition, fit is associated with more active work and organizational attitude and a lower turnover rate. From this perspective, it is clear that person-environment fit has a great positive potential for the organization and person-environment misfit on the other hand is not desirable. In terms of social impact, the unhappiness of those who are facing the misfit can be clearly seen in their behavior in seeking better opportunities outside the organization. Furthermore, employees 
who experience misfit tend not to perform in their jobs and fail to fulfil the organizational needs and expectations. Although misfit may be felt mostly by the individual, it is likely to have broad negative ramifications including turnover intention.

In conclusion, COVID-19 is a worldwide pandemic that puts a halt to economic activity and poses a severe risk to overall well-being. Due to the outbreak, the increasing number of unemployment creates pressure on employees. The International Labour Organization (ILO) estimates that 195 million full-time workers will lose their jobs worldwide this year (International Labour Organization, 2020). Therefore, employees need to learn new skills to improve employability (Gigauri, 2020). The company's current process to respond to the pandemic is complex, generating many negative but also some positive results. Employees and organizations are adapting to the new reality in order to achieve results. It is a must for the organization especially human resource management to take prudent steps to revise company policies to ensure that their current employees stay with the organization and to reduce fear on job security and avoid person-environment misfit from occurring due to new working norms. Employee well-being is a crucial part in an organization and it should not be overlooked by the organization because employees are the assets of the company.

\section{References}

Adewale, A. A. (2015). Perceived job insecurity: Its individual, organisational and societal effects. European Scientific Journal, ESJ Decemb(January), 100-118.

Akgunduz, Y., \& Eryilmaz, G. (2018). Does turnover intention mediate the effects of job insecurity and co-worker support on social loafing? International Journal of Hospitality Management, 68(September 2017), 41-49. https://doi.org/10.1016/j.ijhm.2017.09.010

Al-Omari, K., \& Okasheh, H. (2017). The influence of work environment on job performance: A case study of engineering company in Jordan. International Journal of Applied Engineering Research, 12(24), 15544-15550.

Arijanto, A., Marlita, D., Suroso, A., \& Purnomo, R. (2020). How is the Effect of Job Insecurity, Work Stress, and the Work Environment on Turnover Intention: A Case Study at the Company of Supplier Security System in Indonesia. 120(Icmeb 2019), 114-119. https://doi.org/10.2991/aebmr.k.200205.022

Awan, A. G., \& Tahir, M. T. (2015). Impact of working environment on employee's productivity: A case study of Banks and Insurance Companies in Pakistan. European Journal of Business and Management, 7(1), 329-347.

Brougham, D., \& Haar, J. (2020). Technological disruption and employment: The influence on job insecurity and turnover intentions: A multi-country study. Technological Forecasting and Social Change, 161(September). https://doi.org/10.1016/j.techfore.2020.120276

Carnevale, J. B., \& Hatak, I. (2020). Employee adjustment and well-being in the era of COVID19: Implications for human resource management. Journal of Business Research, 116, 183-187. https://doi.org/10.1016/j.jbusres.2020.05.037

Yin-Fah, C. B., Foon, Y. S., Chee-Leong, L., \& Osman, S. (2010). An Exploratory Study on Turnover Intention among Private Sector Employees. International Journal of Business and Management, 5(8), 57-64. https://doi.org/10.5539/ijbm.v5n8p57 
Chawla, N., MacGowan, R. L., Gabriel, A. S., \& Podsakoff, N. P. (2020). Unplugging or staying connected? Examining the nature, antecedents, and consequences of profiles of daily recovery experiences. Journal of Applied Psychology. https://doi.org/10.1037/apl0000423

Chen, H., \& Eyoun, K. (2021). Do mindfulness and perceived organizational support work? Fear of COVID-19 on restaurant frontline employees' job insecurity and emotional exhaustion. International Journal of Hospitality Management, 94(December 2020), 102850. https://doi.org/10.1016/j.ijhm.2020.102850

Cheng, G. H. L., \& Chan, D. K. S. (2008). Who suffers more from job insecurity? A metaanalytic review. Applied Psychology, 57(2), 272-303. https://doi.org/10.1111/j.14640597.2007.00312.x

Chi, N. W., Fang, L. C., Shen, C. T., \& Fan, H. L. (2020). Detrimental Effects of Newcomer Person-Job Misfit on Actual Turnover and Performance: The Buffering Role of Multidimensional Person-Environment Fit. Applied Psychology, 69(4), 1361-1395. https://doi.org/10.1111/apps.12225

Cooper-Thomas, H. D., \& Wright, S. (2013). Person-environment misfit: The neglected role of social context. Journal of Managerial Psychology, 28(1), 21-37.

https://doi.org/10.1108/02683941311298841

Desmond-Hellmann, S. (2020, April 3). Preparing for the Next Pandemic. Retrieved July 17, 2021, from https://www.wsj.com/articles/preparing-for-the-next-pandemic11585936915

Dhanpat, N., Manakana, T., Mbacaza, J., Mokone, D., \& Mtongana, B. (2019). Exploring retention factors and job security of nurses in Gauteng public hospitals in South Africa. African Journal of Economic and Management Studies, 10(1), 57-71. https://doi.org/10.1108/AJEMS-10-2018-0311

Diab-Bahman, R., \& Al-Enzi, A. (2020). The impact of COVID-19 pandemic on conventional work settings. International Journal of Sociology and Social Policy, 40(9-10), 909-927. https://doi.org/10.1108/IJSSP-07-2020-0262

Elmadağ, A. B., \& Ellinger, A. E. (2018). Alleviating job stress to improve service employee work affect: the influence of rewarding. Service Business, 12(1), 121-141. https://doi.org/10.1007/s11628-017-0340-y

Etehadi, B., \& Karatepe, O. M. (2019). The impact of job insecurity on critical hotel employee outcomes: The mediating role of self-efficacy. Journal of Hospitality Marketing and Management. https://doi.org/10.1080/19368623.2019.1556768

Filipkowski, M., \& Johnson, C. M. (2008). Comparisons of performance and job insecurity in union and nonunion sites of a manufacturing company. Journal of Organizational Behavior Management, 28(4), 218-237.

https://doi.org/10.1080/01608060802454437

Follmer, E. H., Talbot, D. L., Kristof-Brown, A. L., Astrove, S. L., \& Billsberry, J. (2018). Resolution, relief, and resignation: A qualitative study of responses to misfit at work. Academy of Management Journal, 61(2), 440-465. https://doi.org/10.5465/amj.2014.0566

Gigauri, I. (2020). Effects of Covid-19 on Human Resource Management From the Perspective of Digitalization and Work-Life-Balance. International Journal of Innovative Technologies in Economy, 4(31).

https://doi.org/10.31435/rsglobal_ijite/30092020/7148 
Griep, Y., Lukic, A., Kraak, J. M., Bohle, S. A. L., Jiang, L., Vander Elst, T., \& De Witte, H. (2021). The chicken or the egg: The reciprocal relationship between job insecurity and mental health complaints. Journal of Business Research, 126, 170-186. https://doi.org/10.1016/j.jbusres.2020.12.045

Hobfoll, S. E. (1989). Conservation of Resources: A New Attempt at Conceptualizing Stress. American Psychologist. https://doi.org/10.1037/0003-066X.44.3.513

Hobfoll, S. E., Halbesleben, J., Neveu, J.-P., \& Westman, M. (2018). Conservation of Resources in the Organizational Context: The Reality of Resources and Their Consequences. Annual Review of Organizational Psychology and Organizational Behavior. https://doi.org/10.1146/annurev-orgpsych-032117-104640

Huang, W., Yuan, C., \& Li, M. (2019). Person-job fit and innovation behavior: Roles of job involvement and career commitment. Frontiers in Psychology, 10(MAY), 1-10. https://doi.org/10.3389/fpsyg.2019.01134

Hixon, T. (2020, March 16). Get Ready To Live With COVID-19. Retrieved July 23, 2021, from https://www.forbes.com/sites/toddhixon/2020/03/12/get-ready-to-live-with-covid19/\#26f55d347824

International Labour Organization. (2020). Impact of the COVID-19 crisis on loss of jobs and hours among domestic workers. June, 1-10. https://coronavirus.jhu.edu/

Jung, H. S., Jung, Y. S., \& Yoon, H. H. (2021). COVID-19: The effects of job insecurity on the job engagement and turnover intent of deluxe hotel employees and the moderating role of generational characteristics. International Journal of Hospitality Management, 92(September 2020), 102703. https://doi.org/10.1016/j.ijhm.2020.102703

Karatepe, O. M., Rezapouraghdam, H., \& Hassannia, R. (2020). Job insecurity, work engagement and their effects on hotel employees' non-green and nonattendance behaviors. International Journal of Hospitality Management, 87(April 2019), 102472. https://doi.org/10.1016/j.ijhm.2020.102472

Kim, M. J., \& Kim, B. J. (2020). The performance implications of job insecurity: The sequential mediating effect of job stress and organizational commitment, and the buffering role of ethical leadership. International Journal of Environmental Research and Public Health, 17(21), 1-16. https://doi.org/10.3390/ijerph17217837

Kniffin, K. M., Narayanan, J., Anseel, F., Antonakis, J., Ashford, S. P., Bakker, A. B., Bamberger, P., Bapuji, H., Bhave, D. P., Choi, V. K., Creary, S. J., Demerouti, E., Flynn, F. J., Gelfand, M. J., Greer, L. L., Johns, G., Kesebir, S., Klein, P. G., Lee, S. Y., ... Vugt, M. van. (2021). COVID-19 and the workplace: Implications, issues, and insights for future research and action. American Psychologist, 76(1), 63-77. https://doi.org/10.1037/amp0000716

Kristof, A. L. (1996). Person-organization fit: An integrative review of its conceptualizations, measurement, and implications. Personnel Psychology, 49(1), 1-49. https://doi.org/10.1111/j.1744-6570.1996.tb01790.x

Lee, S. H., \& Jeong, D. Y. (2017). Job insecurity and turnover intention: Organizational commitment as mediator. Social Behavior and Personality, 45(4), 529-536. https://doi.org/10.2224/sbp.5865

Maertz, C. P., \& Campion, M. A. (2004). Profiles in quitting: Integrating process and content turnover theory. Academy of Management Journal, 47(4), 566-582. https://doi.org/10.2307/20159602

Memon, M. A., Rohani, S., Shahrina, M. N., Jun-Hwa, C., Hiram, T., \& Francis, C. (2018). Person-organisation fit and turnover intention: The mediating role of work engagement. Journal of Management Development, 25(8). 
Miana, B. S., González-Morales, M. G., Caballer, A., \& Peiró, J. M. (2011). Consequences of Job Insecurity and the Moderator Role of Occupational Group. The Spanish Journal of Psychology, 14(2), 820-831. https://doi.org/10.5209/rev_sjop.2011.v14.n2.29

Nella, D., Panagopoulou, E., Galanis, N., Montgomery, A., \& Benos, A. (2015). Consequences of Job Insecurity on the Psychological and Physical Health of Greek Civil Servants. BioMed Research International, 2015. https://doi.org/10.1155/2015/673623

Nugraha, E., \& Garin, H. M. (2019). The influence of career growth and job insecurity on turnover intention of outsourcing workers in port services field companies. Russian Journal of Agricultural and Socio-Economic Sciences.

https://doi.org/10.18551/rjoas.2019-06.33

Sacco, D. F., \& Ismail, M. M. (2014). Social belongingness satisfaction as a function of interaction medium: Face-to-face interactions facilitate greater social belonging and interaction enjoyment compared to instant messaging. Computers in Human Behavior, 36, 359-364. https://doi.org/10.1016/j.chb.2014.04.004

Skelton, A. R., Nattress, D., \& Dwyer, R. J. (2020). Predicting manufacturing employee turnover intentions. Journal of Economics, Finance and Administrative Science, 25(49), 101-117. https://doi.org/10.1108/JEFAS-07-2018-0069

Stiglbauer, B., Selenko, E., Batinic, B., \& Jodlbauer, S. (2012). On the link between job insecurity and turnover intentions: Moderated mediation by work involvement and well-being. Journal of Occupational Health Psychology, 17(3), 354-364. https://doi.org/10.1037/a0028565

Tong, J., Wang, L., \& Peng, K. (2015). From person-environment misfit to job burnout: Theoretical extensions. Journal of Managerial Psychology, 30(2), 169-182. https://doi.org/10.1108/JMP-12-2012-0404

Uppal, N. (2020). Mediating effects of person-environment fit on the relationship between high-performance human resource practices and firm performance. International Journal of Manpower, 42(3), 356-371. https://doi.org/10.1108/IJM-10-2019-0476

Urbanaviciute, I., De Witte, H., \& Rossier, J. (2019). Perceived job insecurity and self-rated health: Testing reciprocal relationships in a five-wave study. Social Science and Medicine, 233(May), 201-207. https://doi.org/10.1016/j.socscimed.2019.05.039

Urbanaviciute, I., Udayar, S., Maggiori, C., \& Rossier, J. (2020). Precariousness Profile and Career Adaptability as Determinants of Job Insecurity: A Three-Wave Study. Journal of Career Development, 47(2), 146-161. https://doi.org/10.1177/0894845318791777

Van Hootegem, A., De Witte, H., De Cuyper, N., \& Elst, T. Vander. (2019). Job Insecurity and the Willingness to Undertake Training: The Moderating Role of Perceived Employability. Journal of Career Development, 46(4), 395-409. https://doi.org/10.1177/0894845318763893

Wheeler, A. R., Halbesleben, J. R. B., \& Shanine, K. (2013). Exploring the Middle Range of Person-Environment Fit Theories through a Conservation of Resources Perspective. Organizational Fit: Key Issues and New Directions, 170-194. https://doi.org/10.1002/9781118320853.ch8

Williamson, M. K., \& Perumal, K. (2021). Exploring the consequences of person-environment misfit in the workplace: a qualitative study. SA Journal of Industrial Psychology, 47, 112. https://doi.org/10.4102/sajip.v47i0.1798

World Health Organization (WHO) (2021). WHO Coronavirus (COVID-19) Dashboard. Retrieved July 26, 2021, from https://covid19.who.int/ 